\title{
The Sadomasochism Checklist: A Tool for the Assessment of Sadomasochistic Behavior
}

\author{
Roland Weierstall $^{1} \cdot$ Gilda Giebel $^{1}$
}

Received: 20 November 2014 / Revised: 19 March 2016 / Accepted: 6 June 2016 / Published online: 3 August 2016

(C) The Author(s) 2016. This article is published with open access at Springerlink.com

\begin{abstract}
Various scientific disciplines devoted to the study of sexual behavior are concerned with the understanding of sadomasochistic (SM) practices. However, only a fragmented body of theories, opinions, and studies is available, which limits the systematic study of this field. Empirical studies and tools for the assessment of SM tendencies are particularly sparse. Our aim was to develop a comprehensive tool for the assessment of an individual's engagement in SM practices. A comprehensive 24-item checklist of different types of SM play was generated with the assistance of members of the German SM community, covering both a dominance scale and a submission scale. The sadomasochism checklist was administered in an online study to a sample of 652 adults ( 345 female, 307 male), with 527 participants being active members in the SM community. Both the frequency of SM behavior and the attraction to the types of SM practices were assessed. Results revealed a onefactor structure for the dominance as well as the submission scale. The distinction between different types of practices (soft play, domination/submission, beating, toys, breath and bodily fluids) was confirmed using principal component analysis. Cronbach's alpha was appropriate. The total scores for the dominance and the submission scale distinguish between participants with different preferences for dominant and submissive practices. The newly developed scale is a reliable and valid tool for the assess ment of the frequency of and attraction to SM behavior. It aims to provide the basis for future systematic studies on sadomasochism.
\end{abstract}

Keywords Sadomasochism · BDSM · Self-assessment . Reliability · Validity

Roland Weierstall

roland.weierstall@uni-konstanz.de

1 Department of Psychology, University of Konstanz, 78457 Constance, Germany

\section{Introduction}

The term sadomasochism (SM) finds its origins in two concepts: (1) sadism, which itself is linked to Comte marquis de Sade (1740-1814), whose writings covered sexual cruelty in an erotic sense, and (2) masochism, which derives from the writer Masoch (1836-1905), whose novels reflected erotic appeal by pain, submission, and humiliation (Cleugh, 1952). Most of the early knowledge gained on SM behavior can be traced back to the early psychoanalytic work of Freud (1938) or Kraft-Ebbing (1965). Thus, it mainly stems from clinical observations in patients suffering from their SM tendencies and not from observations in the general population (Weinberg, 2006). This clinical perspective that considers SM practices as a psychopathological deviation has consequently shaped the early conceptualization of SM behavior. It was not until the 1970s and 1980s that a growing body of literature from the social sciences broadened the perspective toward a nonpathological view on SM behavior (Weinberg, 1994). However, even though this more recent literature utilized a broad variety of different quantitative and qualitative methods, the nature of SM is still incompletely understood. We therefore claim that sexual science would benefit from a more systematic assessment of SM practices and in particular, from tools that allow representative observations. This would in turn also help to increase the comparability of different studies and promote a more objective approach toward the understanding of the SM phenomenon.

Bondage and discipline, dominance and submission, sadism and masochism (BDSM) (Connolly, 2006) was often viewed as a controversial type of human sexual behavior, as it can incorporate activities that might appear to resemble a sexual assault (Beres, 2007). This perceived pathological or abnormal deviance was fueled by the fact that sexual sadism and sexual masochism appeared as paraphilic disorders in the psychiatric classification systems for mental disorders. As noted by Krueger (2010a, 2010b), the occurrence of both diagnoses in the classification systems per se 
is necessary, as they can be prominent among clinical populations and in forensic samples, presenting clear targets for treatment as well as the prevention of future assaults. However, Krueger also argued for a more structured and empirically based approach tow ard the understanding of pathological deviations of sadistic and ma sochistic tendencies that can be distinguished from a variant of nondeviant sexuality. In the latest edition of the Diagnostic and Statistical Manual of Mental Disorders (American Psychiatric Association, 2013), a subtle but crucial change was made: the terms sexual sadism and sexual masochism were changed into sexual sadism disorder and sexual masochism disorder, to draw a line between deviant and pathological sexual behavior. For being diagnosed with a paraphilic disorder, the DSM-5 requires that people with an interest in SM practices would either (1) have to "feel personal distress about their interest, not merely distress resulting from society's disapproval" or (2) have to "have a sexual desire or behavior that involves another person's psychological distress, injury, or death, or a desire for sexual behaviors involving unwilling persons or persons unable to give legal consent." These criteria are used to distinguish pathological from non-pathological forms of SM practices.

In sexual science, the historically based pathologization is likewise often opposed with the play-like behavior that considers $\mathrm{SM}$ as a consensual, careful, and collaborative sexual behavior, apart from any pathological deviations (Hoople, 1996; Moser, 1998). One of the most common distinctions between non-pathological and pathological SM behavior is the differentiation between consent between the two partners and coercion (Moser \& Kleinplatz, 2007). This view on SM is also often shared within the SM communities, which have consensual SM play and sex as prime principles (Pitagora, 2013; Sagarin, Cutler, Cutler, LawlerSagarin, \& Matuszewich, 2009).

Studies on consensual BDSM offer a diversity of interesting research questions concerning the nature of SM tendencies, its relation to other associated constructs, such as satisfaction in relationships, early childhood development, or character traits, as well as its relevance for practical applications. Williams (2009) particularly emphasized positive consequences of SM in relationships: Williams suggested that professionals working in the field of sexual sciences have to consider that SM practices—under safe participation — can promote intimacy and creative stimulation in partnerships. This matches studies in which it was demonstrated that heterosexuals and homosexuals who are active in BDSM practices are also more open to other sexual experiences(Richters, de Visser, Rissel, Grulich, \& Smith, 2008) and report various benefits of their interest in BDSM (Hébert \& Weaver, 2015). Relations between the attraction to SM practices and character traits that have been discussed in the early literature, such as a lack of self-confidence, neuroticism, and extraversion, were in turn not found (Pokroppa, 1999). Empirical studies could also demonstrate that masochists did not score higher in mental instability and that people with sadistic sexual interest did not have higher values in antisocial or psychotic traits than people with conventional sexual preferences (Cross \& Matheson, 2006). These examples of current research all support the view that there is no evidence that SM practition-

ers deviate from the general population in a pathological way (Moser \& Kleinplatz, 2006; Nichols, 2006). Large-scale empirical studies are therefore a valuable source to objectify views on consensual SM play and help uncover and identify the functionality of SM practices.

In the present article, we describe the development of a comprehensive 24-item checklist for the assessment of an individual's attraction to sadomasochism, covering both dominant and submissive practices. The items in the checklist as well as the results on psychometric properties of the checklist were derived from an online study conducted with a sample of participants mainly from the German SM community. For item construction, we considered literature on different types of SM play (e.g., Alison, Santtila, Sandnabba, \& Nordling, 2001; Ernulf \& Innala, 1995) from an extensive literature review. Moreover, we received support from experienced members of the German SM community. To draw a representative sample from the German SM community, we utilized an online assessment that was promoted on central nationwide websites of the community. This checklist aims to provide an objective tool for future research on SM play in sexual science and validly distinguish between individuals with a different attraction to SM fantasies and practices.

\section{Method}

\section{Participants}

An online survey was administered to a German population after contacting mailing lists and SM communities (e.g., www.smhh.de, SM netpublishing, SM "Stammtisch" of different German cities). The link with the invitation to participate in a study about sadomasochism and sexual diversity was also sent to different e-mail distribution lists of student associations and social networks in order to recruit non-BDSM participants. These served as a reference group for the study population to compare the participants' pleasure gain and frequency of SM behavior between groups with different attraction to SM practices. Altogether, the website was accessed 1519 times. A total of 1145 participants started the online survey, of which 652 completed the full survey (345 female participants, 307 male participants).

The age range was $18-60$ years $(M=39, S D=11.7)$. At the beginning of the study, participants had to make a declaration about their SM self-perception, meaning whether they would describe themselves as "dominants," "submissives," "switches," or if they had no particular attraction to sadomasochism. People who preferred playing the dominant role in SM practices were named "dominants" $(N=136,26$ females), people who preferred the submissive role were named "submissives" $(N=230$, 
170 females), and people who enjoyed both sides and switched the SM roles were named "switches" ( $N=155,74$ females). A total of 131 participants ( 75 females) had no explicit SM interest ("conventional group"). A $\chi^{2}$-test revealed a significant difference in the distribution between females and males across the groups of dominants, submissives, and switches, $\chi^{2}(2)=105.70$, $p<.001$. Comparisons of the proportions of female and male participants among the three groups demonstrated that more males were in the group of dominants than in the other two groups of switches, $\chi^{2}(1)=26.32, p<.001$, and submissives, $\chi^{2}(1)=$ $103.17, p<.001$. Likewise, more women were in the group of submissives than in the group of switches, $\chi^{2}(1)=27.33, p<$ .001 and dominants (see above). The primary sexual orientation was measured using a 8-point "slider scale," ranging from hetero sexual ("0") to homosexual ("7"): $56 \%$ of the participants indi cated being heterosexual, $17 \%$ bisexual, and $10 \%$ homosexual. The remaining $17 \%$ felt dedicated to possibilities between the three options. Attendees participated voluntarily. Ethical rev iew boards approved the study.

\section{Measures}

\section{Construction of the Checklist}

For item generation, we collected different kinds of SM practices while investigating the scientific literature (e.g., Alison et al., 2001; Ernulf \& Innala, 1995), webpages from SM communities, and personal communication with members of the BDSM scene. We ended up with a selection of 24 items that depicted a wide and common range of different SM practices. Each item was administered both in the active voice (SMCL dominance scale, e.g., "Spanking your partner") and the passive voice (SMCL submission scale: e.g., "Getting spanked by your partner"). However, due to the great variety of different fantasies and tendencies (for a comprehensive list see Rehor, 2015), some items subsumed different types of SM behaviors. We grouped the items by content into six clusters which summed up different facets of submission or domination (for the final SMCL scales, see Appendix 1 for the Submission scale and Appendix 2 for the SMCL Dominance scale): We started with items that belong to beginner SM practices-for example, blindfolding the partner or getting blindfolded, following somebody's commands or having hard intercourse - and named the first group "soft play." Every sexual activity which shows a slope in hierarchy between the partner, such as role play with dominant/submissive roles, verbal humiliation or humiliating the submissive partner with others, belonged to the second group, "domination." "Beatings" were the third group of sexual SM practices included in the checklist, covering spanking, whipping, and light beating. As sex toys such as clamps, plugs, and wax are common tools in SM practices, the fourth group of SM practices covering these items was labeled "toys." Some SM users apply breath con trol games while strangling the bottom partners or use body fluids such as urine or feces. We therefore named the fifth group of SM practices "breathing" and the sixth "body fluids."

For each item, participants had to indicate whether they have had no experiences at all with the respective practice (coded “0”), if it occurs as a masturbation fantasy (coded “ 1 ”), or if they practice or practiced it in real life (coded “2”). Particip ants additionally had to rate their personal sexual pleasure gain from each practice on a five-point scale ranging from 0 (not at all) to 4 (extremely) from their current perspective. As sexual experiences shape future sexual preferences and activities (O'Donovan, 2010), no specific timeframe for experiences with SM fan tasies or behavior was set. For each item, participants could select one response for prior experience and one response for pleasure gain.

\section{Procedure}

The online questionnaire was accessed through a link in the invitation e-mail and was administered through unipark.de. Informed consent information was provided, and participants' consents were obtained by clicking "I agree" before being directed to the survey questions. Participation was anonymous and took approximately 15-20 min to complete.

\section{Data Analysis}

The two scales (Submission scale and Dominance scale) were analyzed separately to improve the fit of the two scales for the respective target populations. For the Submission scale, analyses were based on data of the groups of submissives and switches. For the dominance scale, analyses were based on data of the groups of dominants and switches. To evaluate if items had to be discarded, factor analysis with principal axis factoring was conducted in a first step. In a second step, principal axis factoring with varimax rotation was undertaken with eigenvalues $>1$ to explore the underlying factor structure of the two subscales in relation to the theoretically proposed dimensions of SM practices. To investigate, whether the engagement in SM practices was related to pleasure gain, Spearman rank coefficients were calculated item-wise for the relation between pleasure gain and engagement in SM plays. Spearman rank coefficients were chosen due to the ordinally scaled assessment of the engagement in SM practices. For the total scores of the dominance and the submission scale, non-parametric MannWhitney $U$ tests were calculated for differences between male and female participants. Kruskal-Wallis tests were used for the comparison of the total scores across study groups of dominants, submissives, switches, and the conventional group. Mann-Whitney $U$ tests with Bonferroni-corrected $p$-values were calculated for multiple comparisons between scores across groups. Nonparametric tests were chosen due to unequal variances and sample sizes across groups. The data were processed using SPSS 21, applying a cutoff level for significance of $p<.05$. Effect sizes 
were calculated using g*power 3.1 (Faul, Erdfelder, Lang, \& Buchner, 2007).

\section{Results}

In the following section, the psychometric properties of the two subscales $S M C L$ are described.

\section{SMCL Submission Scale}

\section{Factor Structure and Reliability}

An initial principal component analysis revealed a clear singlefactor structure, with the first factor accounting for $29 \%$ of the scale variance. In addition, the scree test criterion also indicated a clear break between the first and the second factor (Cattell, 1978). The data contained sufficient shared variance for factor analysis (Kaiser-Meyer-Olkin criterion, $\mathrm{KMO}=.85$ ). The reliability of the 24-item scale of Cronbach's alpha $=.96$ was sufficient and all items had statistically significant $(p<.01)$ corrected item total correlations $(M=.47, S D=.10)$. Similarly, the mean factor loading of all 24 items (Table 1 ) onto the first factor was $.53(S D=.12)$.

To additionally reduce the items to a smaller set of independent composite variables, the six non-trivial factors with an eigenvalue higher than 1 were rotated to a varimax solution. These six factors accounted for $64 \%$ of the variance, whereas each factor clustered a subset of items that were interpretable and content-relevant (Table 1): The strongest factor, accounting for $15.22 \%$ of the total variance, was associated with items related to dominance, such as humiliating not only the partner but also with others, or restricting his or her psychological needs. The second factor (explaining $11.26 \%$ of the variance) referred to items assessing the pleasure related to the use of toys that can be used to inflict pain, such as clamps, plugs, or wax. The third factor, accounting for $10.48 \%$ of the total variance, was comprised items assessing rather soft SM play, including soft bondage behavior such as not only blindfolding and restricting the partner, giving commands, but also having "hard" intercourse. Even though the latter item does not seem to be a rather soft item, it still does rather match with the other items in this category compared to other factors. The three items related to beatings loaded onto the fourth factor, sharing $9.95 \%$ of the total variance. For the last two factors, which accounted for 9.59 and $7.57 \%$ of the variance, the items related to breath deprivation and bodily fluids could be, respectively, reflected. Only one item, clawing $_{\text {sub, }}$ showed ambiguous factor loadings (i.e., coefficients not above .5) on three factors. Cronbach's alpha coefficients for the six dimensions were calculated as a measure for reliability and revealed satisfying results (sub-scale domination: .84, sub-scale toys: .80 , sub-scale soft play: 74 , sub-scale beatings: .78, sub-scale breath: .80, and sub-scale body fluids: .63). The lower body fluids reliability could be traced back to the comparably low number of responses to the feces $_{\text {sub }}$ item.

\section{Pleasure Gain and Engagement in Submissive Behavior}

As the engagement in submissive practices was ordinal-scaled and could not be summed up, the relation between pleasure gain and the engagement in certain behaviors was analyzed item-wise, using Spearman correlations. For every item, participants who reported a higher pleasure gain also reported a higher engagement in the corresponding behavior, indicated by masturbation fantasies or real-life experiences (Mean Spearman correlation coefficient $=.61, S D=.11 ;$ all $p s<.001$ ).

\section{Gender Differences}

For both groups of submissives and switches, differences in pleasure gain between female and male participants were calculated for the total score of the scale. Due to unequal numbers of female and male participants in the groups, Mann-Whitney $U$ tests were conducted and revealed neither a statistically significant differences between female and male participants in the group of submissives $(Z=1.85, p=.064, r=.12)$ nor in the group of switches $(Z=.59, p=.557, r=.05)$.

\section{Differences in Pleasure Gain Across Groups for Submissive Practices}

A Kruskal-Wallis test for differences in pleasure gain submissive practices across the four groups revealed a significant main effect of group, $\chi^{2}(3)=409.56, p<.001, \eta_{\mathrm{p}}^{2}=.64$. Post-hoc calculated Bonferroni-corrected Mann-Whitney $U$ tests for multiple comparisons demonstrated medium to large effect sizes for differences across all four groups (Table 2): whereas participants from the group of submissives reported the highest pleasure gain, followed by participants from the group of switches, participants from the group of dominants showed an even lower pleasure gain than participants with a conventional interest.

\section{SMCL Dominance Scale}

\section{Factor Structure and Reliability}

A principal component analysis was carried out on the data from the groups of dominants and switches. In line with the scree test criterion, the initial unrotated factor solution favored a single-factor structure, with the first factor accounting for $29 \%$ and a clear break after the first factor. The result of the KMO measure was .84. For the 24-item scale, Cronbach's alpha was .89. All items had significant corrected item total correlation $(M=.47, S D=.10$; all $p<.01)$. Likewise, all items except the item feces $_{\text {dom }}$ had sufficient factor loadings (Table 3) onto the first factor $(M=.60, S D=.14)$. 
Table 1 One-factor solution and varimax solution for the items of the SMCL Submission scale

\begin{tabular}{|c|c|c|c|c|c|c|c|}
\hline \multirow[t]{2}{*}{ Item } & \multirow{2}{*}{$\begin{array}{l}\text { One-factor } \\
\text { solution } \\
(29.32 \%)\end{array}$} & \multicolumn{6}{|c|}{ Six-factor solution } \\
\hline & & $\begin{array}{l}\text { Domination } \\
(15.22 \%)\end{array}$ & $\begin{array}{l}\text { Toys } \\
(11.26 \%)\end{array}$ & $\begin{array}{l}\text { Soft play } \\
(10.48 \%)\end{array}$ & $\begin{array}{l}\text { Beatings } \\
(9.95 \%)\end{array}$ & $\begin{array}{l}\text { Breath } \\
(9.59 \%)\end{array}$ & $\begin{array}{l}\text { Bodily fluids } \\
(7.57 \%)\end{array}$ \\
\hline 17. Humiliating with others sub $_{\text {su }}$ & .59 & .78 & & & & & \\
\hline 13. Verbal humiliation ${ }_{\text {sub }}$ & .65 & .76 & & & & & \\
\hline 18. Display partner ${ }_{\text {sub }}$ & .62 & .74 & & & & & \\
\hline 11. Role play $y_{\text {sub }}$ & .38 & .63 & & & & & \\
\hline 15. Confinement $t_{\text {sub }}$ & .52 & .60 & & & & & \\
\hline 16. Force against will ${ }_{\text {sub }}$ & .57 & .56 & & & & & \\
\hline 8. Genitals torture sub & .64 & & .79 & & & & \\
\hline 6. Clamps sub & .61 & & .71 & & & & \\
\hline 9. Plugs sub $_{\text {s }}$ & .59 & & .68 & & & & \\
\hline 5. Wax $\mathrm{xub}_{\mathrm{sub}}$ & .47 & & .55 & & & & \\
\hline 12. Blindfolding sub $_{\text {s. }}$ & .43 & & & .73 & & & \\
\hline 14. Tying up $\mathrm{sub}_{\mathrm{s}}$ & .52 & & & .61 & & & \\
\hline 10. Commands sub $_{\text {s. }}$ & .58 & & & .61 & & & \\
\hline 3. Rough intercourse sub $_{\text {s. }}$ & .45 & & & .61 & & & \\
\hline 4. Spanking sub $_{\text {s }}$ & .29 & & & & .88 & & \\
\hline 7. Whipping sub & .41 & & & & .75 & & \\
\hline 2. Light beating sub $_{\text {sub }}$ & .34 & & & & .73 & & \\
\hline 23. Strangling sub $_{\text {s }}$ & .41 & & & & & .87 & \\
\hline 22. Facesitting sub $_{\text {}}$ & .45 & & & & & .78 & \\
\hline 24. Unconscious $s_{\mathrm{sub}}$ & .33 & & & & & .77 & \\
\hline 20. Urinating sub $_{\text {S }}$ & .55 & & & & & & .82 \\
\hline 19. Swallowing sub $_{\text {su }}$ & .68 & & & & & & .64 \\
\hline 21. Feces $\mathrm{sub}$ & .28 & & & & & & .59 \\
\hline 1. Clawing sub & .39 & & & .42 & & .31 & .30 \\
\hline
\end{tabular}

Factor loadings for the one- and six-factor solution after varimax rotation, and the percentages of variance explained by every factor are displayed. For the six-factor solution, only coefficients above 0.5 are presented, except for the ambiguous item clawing $_{\text {dom }}$

To additionally combine the items into smaller subsets, all non-trivial factors with an eigenvalue $>1$ were subsequently varimax rotated (Table 3). The six factors, accounting for 64 $\%$ of the total variance, confirmed a similar conceptual distinctiveness than the varimax solution from the submission items. The six factors contributed to the differentiation of various preferences of sadistic behavior. The first factor (explained variance of 20 . $31 \%$ ) comprised almost the same items as the first factor from the Submission scale and was therefore also associated with SM dominance. The second factor, which accounted for $13.2 \%$ of the variance, was likewise associated with the use of toys such as plugs or clamps in the play with the partner. The third orthogonal factor covered the three items related to beatings and accounted for $11.36 \%$ of the variance. Another three items were grouped by the fourth factor, explaining $9.71 \%$ of the variance and including the three items associated with breath reduction. The fifth $(8.96 \%$ explained variance) and sixth (7.57\% variance) factors included two items each and subsumed soft SM play behavior as well as the two body fluids items feces $_{\mathrm{dom}}$ and urinating $\mathrm{dom}_{\mathrm{do}}$. The three items tying $u p_{\mathrm{dom}}$, swallowing $_{\mathrm{dom}}$, and rough intercourse $e_{\mathrm{dom}}$ could not be associated with one distinctive factor, but seemed to be part of different forms of SM preferences. Cronbach's alpha coefficients for the six dimensions were the following: domination .90 , toys .74 , beatings .92 , breath .78 , soft play .84 , and body fluids .60 . As for the submission items, the lower reliability of body fluids could be traced back to the comparably lower number of responses to the feces $_{\text {dom }}$ item.

\section{Pleasure Gain and Frequency of Sadomasochistic Behavior}

The relation between pleasure gain and the ordinally scaled engagement in sadistic practices was analyzed item-wise, using Spearman correlations. As for the submission scale items, par- 
Table 2 Bonferroni-corrected pairwise comparisons for pleasure gain from submissive behavior across study groups

\begin{tabular}{|c|c|c|c|c|c|c|c|}
\hline \multirow[t]{2}{*}{ Group } & \multicolumn{2}{|c|}{ Pleasure gain } & \multirow[t]{2}{*}{ Comparison group } & \multirow{2}{*}{$\begin{array}{l}\text { Mean } \\
\text { difference }\end{array}$} & \multirow{2}{*}{$\begin{array}{l}\text { Mann-Whitney } \\
U \text { test: } Z\end{array}$} & \multirow{2}{*}{$\begin{array}{l}\text { Bonferroni- } \\
\text { corrected } p \text { value }\end{array}$} & \multirow{2}{*}{$\begin{array}{l}\text { Effect } \\
\text { size } r\end{array}$} \\
\hline & $M$ & $S D$ & & & & & \\
\hline \multirow[t]{3}{*}{ Dominants } & \multirow[t]{3}{*}{8.71} & \multirow[t]{3}{*}{12.49} & Submissives & -51.84 & 15.56 & $<.001$ & .82 \\
\hline & & & Switches & -35.94 & 12.90 & $<.001$ & .76 \\
\hline & & & Conventional group & -11.95 & 6.77 & $<.001$ & .42 \\
\hline \multirow[t]{2}{*}{ Submissives } & \multirow[t]{2}{*}{60.56} & \multirow[t]{2}{*}{15.25} & Switches & 15.90 & 7.94 & $<.001$ & .41 \\
\hline & & & Conventional group & 39.89 & 14.42 & $<.001$ & .76 \\
\hline Switches & 44.66 & 18.47 & Conventional group & 23.99 & 9.62 & $<.001$ & .57 \\
\hline Conventional group & 20.67 & 15.90 & - & & & & \\
\hline
\end{tabular}

Table 3 One-factor solution and varimax solution for the items of the Dominance scale

\begin{tabular}{|c|c|c|c|c|c|c|c|}
\hline \multirow[t]{2}{*}{ Item } & \multirow{2}{*}{$\begin{array}{l}\text { One-factor } \\
\text { solution } \\
(29.11 \%)\end{array}$} & \multicolumn{6}{|c|}{ Six-factor solution } \\
\hline & & $\begin{array}{l}\text { Domination } \\
(20.31 \%)\end{array}$ & $\begin{array}{l}\text { Toys } \\
(13.20 \%)\end{array}$ & $\begin{array}{l}\text { Beatings } \\
(11.36 \%)\end{array}$ & $\begin{array}{l}\text { Breath } \\
(9.71 \%)\end{array}$ & $\begin{array}{l}\text { Soft play } \\
(8.96 \%)\end{array}$ & $\begin{array}{l}\text { Bodily fluids } \\
(7.57 \%)\end{array}$ \\
\hline 13. Verbal humiliation ${ }_{\text {dom }}$ & .49 & .73 & & & & & \\
\hline 18. Display partner ${ }_{\text {dom }}$ & .48 & .69 & & & & & \\
\hline 17. Humiliating with others ${ }_{\text {dom }}$ & .45 & .69 & & & & & \\
\hline 15. Confinement ${ }_{\mathrm{dom}}$ & .42 & .60 & & & & & \\
\hline 11. Role play $_{\mathrm{dom}}$ & .37 & .57 & & & & & \\
\hline 16. Force against will $\mathrm{dom}$ & .43 & .54 & & & & & \\
\hline 10. Commands dom & .40 & .52 & & & & & \\
\hline 8. Genital torture ${ }_{\text {dom }}$ & .63 & & .77 & & & & \\
\hline 6. Clamps ${ }_{\mathrm{dom}}$ & .65 & & .70 & & & & \\
\hline 9. Plugs $_{\text {dom }}$ & .49 & & .64 & & & & \\
\hline 5. Wax $\mathrm{dom}$ & .53 & & .63 & & & & \\
\hline 4. Spanking dom & .70 & & & .91 & & & \\
\hline 2. Light beatings $s_{d o m}$ & .68 & & & .85 & & & \\
\hline 7. Whipping dom & .62 & & & .73 & & & \\
\hline 23. Strangling $g_{d o m}$ & .60 & & & & .85 & & \\
\hline 24. Unconscious $\mathrm{dom}_{\mathrm{d}}$ & .32 & & & & .77 & & \\
\hline 22. Facesitting $\mathrm{dom}$ & .54 & & & & .73 & & \\
\hline 12. Blindfolding $\mathrm{dom}_{\mathrm{d}}$ & .46 & & & & & .81 & \\
\hline 1. Clawing ${ }_{\text {dom }}$ & .47 & & & & & .53 & \\
\hline 20. Urinating dom $_{\text {. }}$ & .38 & & & & & & .76 \\
\hline 21. Feces ${ }_{\text {dom }}$ & .19 & & & & & & .72 \\
\hline 14. Tying up dom & .50 & .44 & .48 & & & .38 & \\
\hline 19. Swallowing dom & .47 & .44 & & & & & .46 \\
\hline 3. Rough intercourse dom & .36 & & & .39 & & .38 & \\
\hline
\end{tabular}

Factor loadings (coefficients above 0.5 ) for the dominance items after varimax rotation, and the percentages of variance explained by every factor are displayed. For the three ambiguous items tying $u p_{\mathrm{dom}}$, swallowing $\mathrm{dom}_{\mathrm{d}}$, and rough intercourse $e_{\mathrm{dom}}$ factor loadings with coefficients above 0.3 are displayed

ticipants who described a higher pleasure gain from dominant behaviors also reported a higher engagement in the respective behaviors (Mean Spearman correlation coefficient $=.55, S D=$ .21 ; all $p \mathrm{~s}<.001)$.

\section{Gender Differences}

Mann-Whitney $U$ tests were conducted for differences in pleasure gain between female and male participants from the groups 
Table 4 Bonferroni-corrected pairwise comparisons for pleasure gain from dominant behavior across study groups

\begin{tabular}{|c|c|c|c|c|c|c|c|}
\hline \multirow[t]{2}{*}{ Group } & \multicolumn{2}{|c|}{ Pleasure gain } & \multirow{2}{*}{$\begin{array}{l}\text { Comparison } \\
\text { group }\end{array}$} & \multirow{2}{*}{$\begin{array}{l}\text { Mean } \\
\text { difference }\end{array}$} & \multirow{2}{*}{$\begin{array}{l}\text { Mann-Whitney } \\
U \text { test: } Z\end{array}$} & \multirow{2}{*}{$\begin{array}{l}\text { Bonferroni-corrected } \\
p \text { value }\end{array}$} & \multirow[t]{2}{*}{ Effect size $r$} \\
\hline & $M$ & $S D$ & & & & & \\
\hline \multirow[t]{3}{*}{ Dominants } & 54.18 & 17.41 & Submissives & 42.44 & 12.19 & $<.001$ & .74 \\
\hline & & & Switches & 9.94 & 4.97 & $<.001$ & .29 \\
\hline & & & Conventional group & 32.81 & 11.35 & $<.001$ & .70 \\
\hline \multirow[t]{2}{*}{ Submissives } & 11.74 & 15.99 & Switches & -32.50 & 13.34 & $<.001$ & .68 \\
\hline & & & Conventional group & -9.62 & 6.73 & $<.001$ & .36 \\
\hline Switches & 44.24 & 18.21 & Conventional group & 22.88 & 9.72 & $<.001$ & .58 \\
\hline Conventional group & 21.36 & 16.50 & - & & & & \\
\hline
\end{tabular}

of dominants and switches. There was neither a statistically significant differences between female and male participants in the group of dominants $(Z=.47, p=.640, r=.04)$ nor in the group of switches $(Z=.56, p=.576, r=.04)$.

\section{Differences in Pleasure Gain across Groups for Dominant Practices}

There was a significant difference in pleasure gain from dominant practices across the four groups, Kruskal-Wallis test: $\chi^{2}(3)=33$ $8.58, p<.001, \eta_{\mathrm{p}}^{2}=.52$. To account for individual group differences, Bonferroni-corrected Mann-Whitney $U$ tests were calculated and revealed medium to large effect sizes for differences across the four groups of participants (Table 4): contrary to the submissive items, participants from the group of dominants reported the highest overall pleasure gain, whereas participants from the group of submissives reported least pleasure gain. Participants from the group of switches reported the second highest pleasure gain, whereas participants from the conventional group scored higher than the group of submissives.

Additionally, paired sample $t$ tests were calculated for differences between the submission and the dominance total score within groups. Significant differences between the two scores were obtained in the two groups of dominants and submissives, dominants: $t(132)=27.61, p<.001, d_{\mathrm{z}}=2.40$; submissives: $t(227)=34.30$, $p<.001, d_{\mathrm{z}}=2.13$, and confirmed clear preferences for one type of SM behavior over the other. No significant differences were found for the other two groups, indicating no consistent preferences, switches: $t(153)<1, d_{\mathrm{z}}=.01$; conventional group: $t(128)<1, d_{\mathrm{z}}=.05$.

\section{Discussion}

The aim was to develop a tool that is useful for the assessment of a person's attraction to SM fantasies and practices. The checklist presented in this article provides two scales that cover submissive and dominant practices. Both scales allow the computation of a reliable and valid total sum score for pleasure gain, as indicated by the factorial validity and satisfying Cronbach's alpha coefficients. Each scale covered six different groups of common SM play (soft play, domination, beating, toys, breath control, and body fluids) that besides minor exceptions have been verified using principal component analyses with varimax rotation. However, due to the unequal factor structure between the submission and dominance scale, the computation of sub-scoresbesides the total scale scores - cannot be recommended based on the results. Differences in pleasure gain not only for dominant and submissive practices across but also within groups clearly demon strate the potential of the checklist to differentiate people with dif ferent SM preferences. Due to the ordinally scaled assessment of the engagement in SM behavior, the computation of a respective sum score is not recommended either. Instead, this measure can rather be used for other purposes, such as selecting subgroups of participants that display a certain type of behavior.

In terms of gender effects, no significant differences in the attraction to the respective SM practices between male and female participants were observed within the groups of dominants, submissives, or switches. This result shows that people that assign themselves to one of the three groups also have clear preferences for the respective dominant and submissive SM plays, independent of gender. However, the differences in the relative frequencies of male and female participants in the groups of submissives, dominants, and switches imply that - under the hypothesis of an equal probability between males and female for inclusion in the study - males more often display an engagement in dominant practices, whereas females take on the submissive part. This result is in line with a recent study about mate preferences that has shown that women have a generally higher preference for a dominant partner than men do (Giebel, Moran, Schawohl, \& Weierstall, 2015). Women also prefer dominant men, and even men who are aggressive, for a short-term relationship and for the purpose of sexual intercourse (Giebel, Weierstall, Schauer, \& Elbert, 2013). 
The checklist also provides the possibility to investigate changes in BDSM preferences in longitudinal studies, in order to review theories about the formation of SM preferences. In contrast to Freud (1938), Baumeister (1988) argued that masochism appears to come first and sadistic pleasure develops later. Baumeister suggested that dominant counterparts are needed for the SM play, and that the sadistic role provides satisfaction for the top because of the empathy with the masochistic partner. Masochism is more common than sadism in sexual fantasies (Friday, 1980) and real life (Greene \& Greene, 1974). Even in this study, almost twice as many participants with submissive than dominant preferences participated. This provides further support for the usefulness of quantitative studies on sadomasochism to clarify the nature, developmental trajectories, and the functionality of this phenomenon.

\section{Limitations}

There is a huge variety of different SM practices corresponding to the diversity of different human behaviors. This newly developed checklist provides information about sexual preferences, covering a wide range of SM play, including "soft play" on the one hand and dangerous breath control games (Lee, Klement, \& Sagarin, 2015) on the other. Nevertheless, the checklist does not include every possible variation of SM. Special plays with, for example, needles, piercings, electrical stimulation, fire plays, and knife play (cutting) are not specifically named, but subsumed under "toys that cause pain." Future research is needed to prove the content validity and comprehensiveness of the scale. Supplementary items could be added if new dimensions of SM play evolve or if particular research questions support weighting of different items.

\section{Conclusion}

Since the third sexual revolution, "the neosexual revolution" (Sigusch, 2000) started in the 1980s, a general openness toward different and unconventional sexual practices has appeared: me mbers and enthusiasts of special sexual preferences and orientations declare themselves as BDSM players, fetishists or drag queens in public events such as the Folsom Street Fair or Kreu zberg Pride or aboard BDSM party ships. Even if this development moves away from pathologizing SM practices, some BDSM practitioners are still concerned about experiencing stigmatization regarding self-disclosure (Bezreh, Weinberg, \& Edgar, 2012). To further study and elaborate the phenomenon of sadomasochism, we have developed a tool for the assessment of SM practices. The SMCL aims to further guide research in this field.

Acknowledgments We are pleased to acknowledge the valuable contribution made by Christian Allnoch. The support from all members of the SM community and the open acceptance of our scientific approach is gratefully acknowledged. We thank all web portals that kindly supported our research.

Open Access This article is distributed under the terms of the Creative Commons Attribution 4.0 International License (http://creativecommo ns.org/licenses/by/4.0/), which permits unrestricted use, distribution, and reproduction in any medium, provided you give appropriate credit to the original author(s) and the source, provide a link to the Creative Commons license, and indicate if changes were made. 


\section{Appendix 1}

In the following you find a list of different sadmasochistic preferences. Please indicate for every item 1) if you have already used it as a masturbation fantasy or ever tried it with your partner and 2) how much it relates to your sexual pleasure.

1. Being clawed, pinched or bitten by your partner during sexual play.

2. Being stimulated by your partner with light beatings.

3. Receiving rough or hart sexual intercourse with your partner.

4. Getting spanked by your partner.

5. Being tormented by your partner using wax or branding.

6. Getting clamps, weights, clips or other devices that cause pain used on your body

7. Getting whipped, paddled or flogged by your partner.

8. Having your genitals tortured by your partner.

9. Getting plugs or other toys put into your body that cause pain.

10. Receiving commands of your partner on how to please her/him.

11. Having the submissive role in bondage and discipline role play.

12. Being blindfolded by your partner.

13. Being verbally humiliated by your partner.

14. Getting tied up by your partner with chains, ropes, belts etc. for total devotion.

15 . Being placed by your partner into a cage or cellar for confinement of the submissive.

16. Being forced by your partner to please her/him against your will.

17. Being humiliated by your partner together with others.

18. Being displayed as subordinate to thers by your partner.

19. Being forced by your partner to swallow her/his sperm/vaginal secretion.

20. Having your partner urinate on you.

21. Being forced by your partner to ingest feces or vomit.

22. Having your breath controlled by your partner, e.g. by facesitting, smothering or toys.

23. Being strangled of suffocated by your partner.

24. Being made unconscious by your partner, e.g. by using a bag.

\section{Abridgement}

clawing $_{\text {sub }}$

light beatings $s_{\text {sub }}$

rough intercourse ${ }_{\text {sub }}$

spanking $_{\text {sub }}$

wax $_{\text {sub }}$

clamps $_{\text {sub }}$

whipping $_{\text {sub }}$

genital torture $_{\text {sub }}$

plugs $_{\text {sub }}$

commands $_{\text {sub }}$

role play sub $_{\text {}}$

blindfolding sub $_{\text {su }}$

verbal humiliation $_{\text {sub }}$

tying $\mathrm{up}_{\mathrm{sub}}$

confinement $_{\text {sub }}$

force against will ${ }_{\text {sub }}$

humiliating with

others $_{\text {sub }}$

display partner $_{\text {sub }}$

swallowing $_{\text {sub }}$

urinating $_{\text {sub }}$

feces $_{\text {sub }}$

facesitting $_{\text {sub }}$

strangling

unconscious $_{\mathrm{sub}}$

\begin{tabular}{|c|c|c|c|c|c|c|c|}
\hline \multirow{2}{*}{\multicolumn{2}{|c|}{ 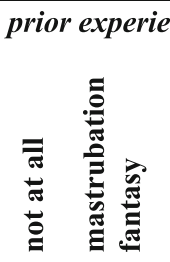 }} & \multirow{2}{*}{ 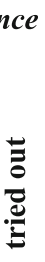 } & \multicolumn{5}{|c|}{ pleasure gain } \\
\hline & & & 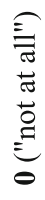 & - & $N$ & $m$ & 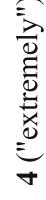 \\
\hline 口 & $\square$ & $\square$ & $\square$ & $\square$ & $\square$ & $\square$ & $\square$ \\
\hline$\square$ & $\square$ & $\square$ & $\square$ & 口 & $\square$ & $\square$ & $\square$ \\
\hline 口 & $\square$ & 口 & 口 & 口 & 口 & $\square$ & $\square$ \\
\hline 口 & 口 & 口 & ב & 口 & 口 & 口 & $\square$ \\
\hline 口 & 口 & 口 & 口 & 口 & 口 & $\square$ & $\square$ \\
\hline 口 & $\square$ & $\square$ & $\square$ & $\square$ & $\square$ & $\square$ & $\square$ \\
\hline 口 & 口 & 口 & 口 & 口 & 口 & 口 & 口 \\
\hline ם & ם & 口 & ם & ם & 口 & a & $\square$ \\
\hline 口 & $\square$ & $\square$ & $\square$ & 口 & 口 & $\square$ & $\square$ \\
\hline 口 & 口 & 口 & 口 & 口 & 口 & 口 & $\square$ \\
\hline 口 & 口 & 口 & 口 & 口 & $\square$ & $\square$ & 口 \\
\hline 口 & 口 & $\square$ & $\square$ & 口 & 口 & 口 & 口 \\
\hline 口 & 口 & 口 & 口 & $\square$ & $\square$ & $\square$ & $\square$ \\
\hline 口 & 口 & 口 & 口 & 口 & $\square$ & $\square$ & $\square$ \\
\hline 口 & 口 & 口 & 口 & 口 & $\square$ & $\square$ & 口 \\
\hline 口 & $\square$ & 口 & 口 & $\square$ & $\square$ & $\square$ & $\square$ \\
\hline 口 & $\square$ & $\square$ & $\square$ & $\square$ & $\square$ & $\square$ & $\square$ \\
\hline 口 & 口 & 口 & 口 & 口 & $\square$ & 口 & $\square$ \\
\hline 口 & 口 & 口 & 口 & 口 & $\square$ & $\square$ & 口 \\
\hline 口 & 口 & 口 & $\square$ & $\square$ & $\square$ & 口 & $\square$ \\
\hline 口 & 口 & 口 & $\square$ & $\square$ & $\square$ & $\square$ & $\square$ \\
\hline 口 & $\square$ & $\square$ & $\square$ & $\square$ & $\square$ & $\square$ & $\square$ \\
\hline 口 & 口 & 口 & 口 & 口 & 口 & $\square$ & $\square$ \\
\hline 口 & 口 & 口 & 口 & 口 & 口 & $\square$ & 口 \\
\hline
\end{tabular}




\section{Appendix 2}

In the following you find a list of different sadmasochistic preferences. Please indicate for every item 1) if you have already used it as a masturbation fantasy or ever tried it with your partner and 2) how much it relates to your sexual pleasure.

Item

1. Clawing, pinching or biting your partner during sexual play.

2. Stimulating your partner with light beatings.

3. Having rough or hart sexual intercourse with your partner.

4. Spanking your partner.

5. Torment your partner using wax or branding

6. Using clamps, weights, clips or other devices that cause pain on your partner's body

7. Whipping, paddling or flogging your partner.

8. Torturing your partner's genitals.

9. Putting plugs or other toys into your partner's body that cause pain to her/him.

10. Giving your partner commands how to please you.

11. Having the dominant role in bondage and discipline role play.

12. Blindfolding your partner.

13. Verbally humiliating your partner.

14. Tying up your partner with chains, ropes, belts etc. for total devotion.

15. Placing your partner into a cage or cellar for confinement of the submissive.

16. Forcing your partner to please you against her/his will.

17. Humiliating your partner with others.

18. Display your partner to others as submissive.

19. Forcing your partner to swallow your sperm/vaginal secretion.

20. Urinating on your partner.

21. Forcing your partner to ingest feces or vomit.

22. Controlling your partner's breath, e.g. by facesitting, smothering or toys.

23. Strangling or suffocating your partner.

24. Making your partner become unconscious, e.g. by using a bag.

\section{Abridgement}

clawing $_{\text {dom }}$

light beatings $\mathrm{s}_{\mathrm{dom}}$

rough intercourse dom

spanking $_{\text {dom }}$

wax $_{\text {dom }}$

clamps $_{\text {dom }}$

whipping $_{\text {dom }}$

genital torture $_{\text {dom }}$

plugs $_{\text {dom }}$

commands $_{\text {dom }}$

role play $_{\text {dom }}$

blindfolding ${ }_{\text {dom }}$

verbal humiliation dom $_{\text {}}$

tying up dom

confinement $_{\text {dom }}$

force against will $\mathrm{dom}_{\mathrm{d}}$

humiliating with

others dom $_{\text {d }}$

display partner dom $_{\text {. }}$

swallowing ${ }_{\text {dom }}$

urinating $_{\text {dom }}$

feces $_{\text {dom }}$

facesitting $_{\text {dom }}$

strangling $g_{\text {dom }}$

unconscious $_{\mathrm{dom}}$

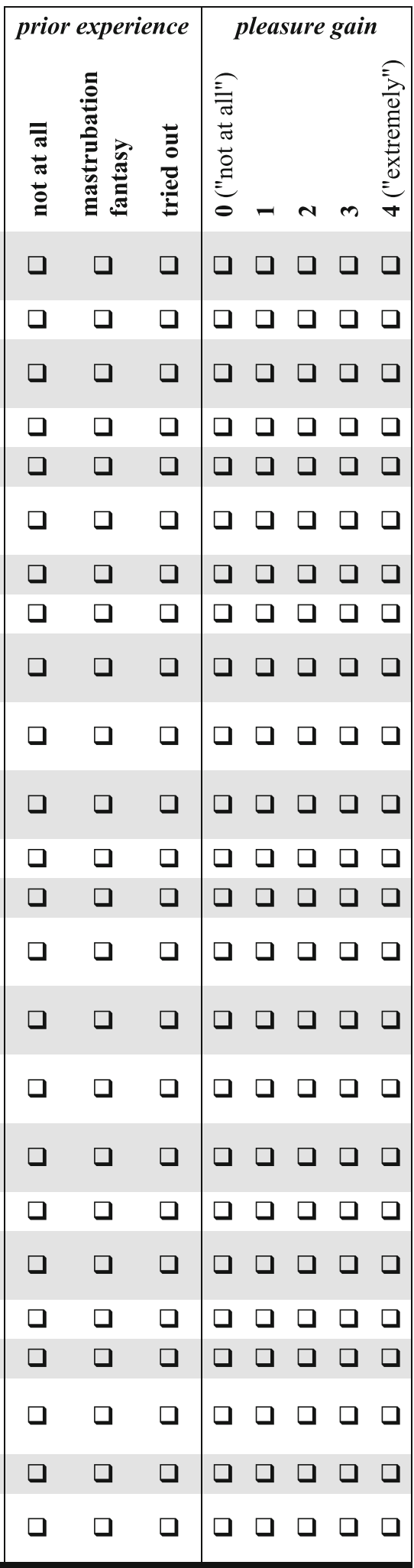




\section{References}

Alison, L., Santtila, P., Sandnabba, N. K., \& Nordling, N. (2001). Sadomasochistically oriented behavior: Diversity in practice and meaning. Archives of Sexual Behavior, 30, 1-12. doi:10.1023/A:1026438422383.

American Psychiatric Association. (2013). Diagnostic and statisticalmanual of mental disorders (5th ed.). Washington, DC: Author.

Baumeister, R. F. (1988). Masochism as escape from self. Journal of Sex Research, 25, 28-59. doi:10.1080/00224498809551444.

Beres, M. A. (2007). 'Spontaneous' sexual consent: An analysis of sexual consent literature. Feminism \& Psychology, 17, 93-108. doi:10.1177/ 0959353507072914.

Bezreh, T., Weinberg, T. S., \& Edgar, T. (2012). BDSM disclosure and stigma management: Identifying opportunities for sex education. American Journal of Sexuality Education, 7,37-61. doi:10.1080/15546128.2012. 650984.

Cattell, R. B. (1978). The scientific use offactor analysis in the behavioral and life sciences. New York: Scientific Plenum Press.

Cleugh, J. (1952). The Marquis and the Chevalier. New York: Duell, Sloan and Pearce.

Connolly, P. H. (2006). Psychological functioning of bondage/domination/ sado-masochism (BDSM) practitioners. Journal of Psychology \& Human Sexuality, 18, 79-120. doi:10.1300/J056v18n01_05.

Cross, P. A., \& Matheson, K. (2006). Understanding sadomasochism: An empirical examination of four perspectives. Journal of Homosexuality, 50, 133-166. doi:10.1300/J082v50n02_07.

Ernulf, K. E., \& Innala, S. M. (1995). Sexual bondage: A review and unobtrusive investigation. Archives of Sexual Behavior, 24, 631-654. doi:10. 1007/BF01542185.

Faul, F., Erdfelder, E., Lang, A. G., \& Buchner, A. (2007). GPower 3: A flexible statistical power analysis program for the social, behavioral, and biomedical sciences. Behavior Research Methods, 39, 175-191. doi:10. 3758/BF03193146.

Freud, S. (1938). Sadism and masochism. In A. A. Brill (Ed.), Basic writings of Sigmund Freud (pp. 30-32). New York: Modern Library.

Friday, N. (1980). Men in love. New York: Dell.

Giebel, G., Moran, J., Schawohl, A., \& Weierstall, R. (2015). The thrill of loving a dominant partner: Relationships between preference for a dominant mate, sensation seeking, and trait anxiety. Personal Relationships, 22, 275-284. doi:10.1111/pere.12079.

Giebel, G., Weierstall, R., Schauer, M., \& Elbert, T. (2013). Female attraction to appetitive-aggressive men is modulated by women's menstrual cycle and men's vulnerability to traumatic stress. Evolutionary Psychology, 11, 248-262. doi:10.1177/147470491301100122.

Greene, G., \& Greene, C. (1974). SM: The last taboo. New York: Grove Press.

Hébert, A., \& Weaver, A. (2015). Perks, problems, and the people who play: A qualitative exploration of dominant and submissive BDSM roles. Canadian Journal of Human Sexuality, 24, 49-62. doi:10.3138/cjhs. 2467.

Hoople, T. (1996). Conflicting visions: SM, feminism and the law-a problem of representation. Canadian Journal of Law and Society, 11(1), 177220.

Krafft-Ebbing, R.(1965). Psychopathia sexualis: With especial reference to the antipathic sexual instinct: A medico-forensic study. New York: Arcade Publishing.
Krueger, R. B. (2010a). The DSM diagnostic criteria for sexual masochism. Archives of Sexual Behavior, 39, 346-356. doi:10.1007/s10508-0109613-4.

Krueger, R. B. (2010b). The DSM diagnostic criteria for sexual sadism. Archives of Sexual Behavior, 39, 325-345. doi:10.1007/s10508-0099586-3.

Lee, E. M., Klement, K. R., \& Sagarin, B. J. (2015). Double hanging during consensual sexual asphyxia: A response to Roma, Pazzelli, Pompili, Girardi, and Ferracuti (2013) [Letter to the Editor]. Archives of Sexual Behavior, 44, 1751-1753. doi:10.1007/s10508-015-0575-4.

Moser, C. (1998). S/M(sadomasochistic) interactions in semi-public settings. Journal of Homosexuality, 36, 19-29. doi:10.1300/J082v36n02_02.

Moser, C., \& Kleinplatz, P. J. (2006). DSM-IV-TR and the paraphilias. Jour nal of Psychology \& Human Sexuality, 17, 91-109. doi:10.1300/J05 6v17n03_05.

Moser, C., \& Kleinplatz, P. J. (2007). Themes of SM expression. In D. Langdridge, M. Barker, D. Langdridge, \& M. Barker (Eds.), Safe, sane and consensual: Contemporary perspectives on sadomasochism (pp. 3554). New York: Palgrave Macmillan.

Nichols, M. (2006). Psychotherapeutic issues with “kinky'"clients: Clinical problems, yours and theirs. Journal of Homosexuality, 50, 281-300. doi:10.1300/J082v50n02_14.

O'Donovan, A. (2010). Sex and sexuality across the lifespan. In C. Butler, A. O'Donovan, \& E. Shaw (Eds.), Sex, sexuality and therapeutic practice: A manual for therapists and trainers (pp. 129-159). New York: Routledge/Taylor \& Francis Group.

Pitagora, D. (2013). Consent vs. coercion: BDSM interactions highlight a fine but immutable line. The New School Psychology Bulletin, 10, 27-36.

Pokroppa, S. (1999). Sado-masochismus: Die sadomasochistische Beziehung zu relevanten Persönlichkeitsvariablen. Aachen, Unpublished diploma thesis.

Rehor, J. E. (2015). Sensual, erotic, and sexual behaviors of women from the "kink" community. Archives of Sexual Behavior, 44, 825-836. doi:10.1007/s10508-015-0524-2.

Richters, J., de Visser, R. O., Rissel, C. E., Grulich, A. E., \& Smith, A. M. (2008). Demographic and psychosocial features of participants in bondage and discipline, "sadomasochism" or dominance and submission (BDSM): Data from a national survey. Journal of Sexual Medicine, 7, 1660-1668. doi:10.1111/j.1743-6109.2008.00795.x.

Sagarin, B. J., Cutler, B., Cutler, N., Lawler-Sagarin, K. A., \& Matuszewich, L. (2009). Hormonal changes and couple bonding in consensual sadomasochistic activity. Archives of Sexual Behavior, 38, 186-200. doi:10. 1007/s10508-008-9374-5.

Sigusch, V. (2000). Strukturwandel der Sexualität in den letzten Jahrzehnten. Fortschritte der Neurologie und Psychiatrie, 68,97-106. doi:10.1055/s2000-11620.

Weinberg, T. S. (1994). Research in sadomasochism: A review of sociological and social psychological literature. Annual Review of Sex Research, 5, 257-277.

Weinberg, T. S. (2006). Sadomasochism and the social sciences: A review of the sociological and social psychological literature. Journal of Homosexuality, 50, 17-40. doi:10.1300/J082v50n02_02.

Williams, D. J. (2009). Deviant leisure: Rethinking "the good, the bad, and the ugly". Leisure Sciences, 31, 207-213. doi:10.1080/01490400802 686110 . 